\title{
Peran Perempuan dalam Penanganan Bencana : Studi Meningkatkan Rasa Kemanusiaan Pada Jiwa Perempuan dalam Penanganan Bencana
}

\author{
Muhammad Khoirul hadi al asy Ari ${ }^{1}{ }^{\text {*; }}$ Rini Idayanti ${ }^{2}$; Afitatul Munawiroh ${ }^{3}$ \\ ${ }^{1}$ Fakultas Syariah, Institut Agama Islam Negeri (IAIN) Jember; Fakultas Ekonomi dan Bisnis, Institut Agama \\ Islam Negeri (IAIN) Bone; Fakultas Syariah, Institut Agama Islam Negeri (IAIN) Jember
}

\begin{tabular}{|c|c|}
\hline ARTICLE INFO & ABSTRACT \\
\hline $\begin{array}{l}\text { ARTICLE HISTORY } \\
\text { Received: } 09 \text { Okt. } 2019 \\
\text { Revised: } 09 \text { Okt. } 2019 \\
\text { Accepted: 09 Okt. } 2019\end{array}$ & $\begin{array}{l}\text { Penelitian ini berbasis pada kajian eksploratoris dan library research, tema yang } \\
\text { diangkat adalah Peran Perempuan dalam Penanggulangan Bencana : Studi } \\
\text { Meningkatkan Rasa Kemanusiaan pada Jiwa Perempuan dalam Penanganan } \\
\text { Bencana. Pertama, Apa rasa kemanusiaan itu ? kedua, Bagaimana } \\
\text { pengembangan rasa kemanusiaan pada jiwa perempuan dalam penanggulangan } \\
\text { bencana? ketiga, Bagaimana perwujudan pengembangan rasa kemanusiaan pada } \\
\text { jiwa perempuan dalam penanggulangan bencana? dengan pendekatan } \\
\text { Phenomenologi dan Sosiologi yaitu fenomena dan kegiatan penanggulangan } \\
\text { bencana oleh perempuan untuk membaca pengembangan rasa kemanusiaan pada } \\
\text { jiwa perempuan dalam penanggulangan bencana dan perwujudan } \\
\text { pengembangan rasa kemanusiaan pada jiwa perempuan dalam penanggulangan } \\
\text { bencana. Sedangkan, rasa kemanusiaan pada perempuan dijelaskan melalui } \\
\text { pendekatan konten analisis. Hasil penelitian ini adalah pertama, mengetahui rasa } \\
\text { kemanusiaan pada jiwa perempuan kedua, adanya pengembangan rasa } \\
\text { kemanusiaan pada jiwa perempuan dalam penanggulangan bencana ketiga, } \\
\text { adanya perwujudan pengembangan rasa kemanusiaan pada jiwa perempuan } \\
\text { dalam penanggulangan bencana. }\end{array}$ \\
\hline
\end{tabular}

This research is based on exploratory studies and library research, the theme raised is the Role of Women in Disaster Management: Study of Improving the Sense of Humanity in the Soul of Women in Disaster Management. First, what is humanity? second, how is the development of humanity in the souls of women in disaster management? Third, how do you realize the development of a sense of humanity in the souls of women in disaster management? with the Phenomenology and Sociology approach, namely phenomena and disaster management activities by women to read the development of a sense of humanity in the soul of women in disaster management and the realization of the development of a sense of humanity in the soul of women in disaster management. Meanwhile, the sense of humanity in women is explained through a content analysis approach. The results of this study are the first, knowing the sense of humanity in the souls of women second, the development of a sense of humanity in the souls of women in disaster management third, the realization of the development of a sense of humanity in the souls of women in disaster management.

CONTACT: Muhammad Khoirul hadi al asy Ari $₫$ khoirul @gmail.com 


\section{PENDAHULUAN}

Manusia merupakan makhluk hidup yang diciptakan paling sempurna oleh Tuhan. Di bumi inilah mereka hidup dan bermetamorfosa. Tuhan tidak menciptakan satu manusia saja di bumi ini, melainkan menciptakan beribu-ribu bahkan beratus-ratus ribu untuk bersosialisai dengan sesamanya. Meskipun mereka sama tinggal di bumi tetapi, seluruh manusia di muka bumi ini memiliki beragam suku, adat, bahasa, dan keseharian yang berbeda. Salah satu contoh di pulau Jawa memiliki beragam bahasa seperti bahasa jawa, bahasa madura dan juga bahasa asing.

Dilihat dari beragamnya perbedaan yang sangat menonjol, hal yang harus disadari adalah banyaknya pula bencana yang terjadi di muka bumi ini. Bencana yang mengakibatkan banyak korban sekaligus adalah bencana alam. Indonesia mempunyai wilayah yang sangat rawan akan adanya bencana alam. Selain itu, wilayahnya dilintasi jajaran pegunungan berapi yang diapit oleh dua samudra besar yaitu samudra pasifik dan hindia yang kemungkinan memberikan dampak pada Indonesia akan sering dilanda badai laut yang hebat.

Indonesia merupakan negara yang kaya akan pegunungan, lembah, bukit, lautan dan juga sungai. Padatnya penduduk juga menjadi pemicu banyaknya bencana alam terjadi. Salah satu contohnya seperti sungai yang awalnya jernih menjadi keruh bahkan dipenuhi oleh sampah, dikarenakan adanya sebagian penduduk yang tidak sadar akan pentingnya menjaga dan mencintai alam sekitar. Hal-hal kecil seperti itu dapat menyebabkan tersumbatnya aliran air sungai sehingga mengakibatkan bencana alam yaitu banjir. Banjir nampaknya menjadi bencana alam yang sering terjadi tetapi, banyak warga yang belum memahami pentingnya adanya sungai.

Pegunungan berapi yang banyak di jumpai di Indonesia juga menjadi sebab adanya bencana alam yang terjadi yaitu gempa bumi dan longsor. Bencana alam yang di sebabkan oleh erupsi gunung berapi ini banyak memakan korban. Lantaran, terjadinya bencana alam ini dalam kurun waktu yang cukup singkat. Banyak penduduk yang tidak sempat menyelamatkan diri. Untuk itu, perlu adanya relawan yang dengan ikhlas membantu meringankan beban sebagian penduduk yang menjadi korban bencana alam itu.

Bencana sendiri adalah peristiwa atau rangkaian peristiwa yang mengancam dan mengganggu kehidupan dan penghidupan masyarakat yang disebabkan baik oleh faktor nonalam maupun faktor alam dan manusia sehingga mengakibatkan timbulnya korban jiwa manusia, kerusakan lingkungan, kerugian harta benda dan dampak psikologis. Bencana itu ada macam-macamnya, yaitu bencana alam, bencana sosial, kejadian bencana, gempa bumi, latusan gunung berapi, tsunami, tanah longsor, banjir, banjir bandang, kekeringan, kebakaran, kebakaran hutan dan lahan, angin puting beliung dan gelombang pasang atau badai.

Bencana alam adalah bencana yang diakibatkan oleh peristiwa atau serangkaian peristiwa yang disebabkan oleh alam antara lain berupa gempa bumi, tsunami, gunung meletus, banjir, kekeringan, angin topan dan tanah longsor. Sedangkan bencana non alam adalah bencana yang diakibatkan oleh peristiwa nonalam antara lain berupa gagal modernisasi, epidemi, dan wabah penyakit. Ada juga bencana sosial, bencana sosial adalah bencana yang diakibatkan oleh peristiwa atau serangkaian peristiwa yang diakibatkan oleh manusia yang meliputi konflik sosial antarkelompok atau antarkomunitas masyarakat dan teror. Lantas, kejadian bencana adalah peristiwa bencana yang terjadi dan dicatat berdasarkan tanggal kejadian, lokasi, jenis bencana, korban dan kerusakan. Jika terjadi bencana pada tanggal yang sama dan melanda lebih dari satu wilayah, maka dihitung sebagai satu kejadian. Dan ada lagi yang baru-baru ini terjadi di Indonesia adalah aksi teror, aksi teror sendiri merupakan aksi yang dilakukan oleh setiap orang yang dengan sengaja menggunakan kekerasan atau ancaman kekerasan sehingga menimbulkan korban yang bersifat masal, dengan cara merampas kemerdekaan sehingga 
mengakibatkan hilangnya nyawa dan harta benda, mengakibatkan kerusakan atau kehancuran terhadap obyek-obyek vital yang strategis atau lingkungan hidup fasilitas publik internasinal.

Para relawan yang ikut andil membantu korban bencana alam kebanyakan adalah kaum lakilaki, seakan-akan perempuan dianggap remeh untuk ikut serta menjadi relawan yang membantu korban bencana alam. Hal ini jelas menjadikan perempuan sebagai manusia yang selalu berada di bawah kekuasaan laki-laki.

Sebenarnya menjadi relawan tidak diperuntukan pada laki-laki saja, tetapi perempuan juga bisa ikut serta menjadi relawan seperti laki-laki. Dalam kehidupan ini perempuan tidak diharuskan menadi manusia yang kekuasaanya selalu dibawah laki-laki. Untuk itu perlu adanya kesetaraan gender dalam menjalani kehidupan di muka bumi ini. Untuk memahami konsep gender, perlu memahami perbedaan sex dan gender. Sex adalah perbedaan jenis kelamin secara biologis, sedangkan gender merupakan perbedaan jenis kelamin berdasarkan konstruksi sosial dan konstruksi masyarakat. $^{1}$

Untuk itu, perempuan seharusnya bisa seperti laki-laki. Kalau dilihat dari sifatnya, perempuan cenderung memiliki sifat anggun, lemah lembut dan cengeng. Tetapi dilihat dari sisi lain, ada juga laki-laki yang memiliki sifat seperti perempuan pada yaitu anggun, lemah lembut dan cengeng. Dari situ dapat dilihat bahwasanya kesetaraan gender sudah tercipta dari masyarakat sendiri.

Hal lain yang bisa dijadikan penguat ada dalam sila ke lima pancasila yang berbunyi “ keadilan bagi seluruh rakyat Indonesia “, itu membutikkan di Indonesia sejak dulu sudah ada kesetaraan gender. Tidak adanya kelebihan kekuasaan bagi kaum laki-laki dan adanya perempuan juga tidak harus berada di bawah kekuasaan laki-laki. Perempuan juga bisa seperti laki-laki, begitupun laki-laki juga bisa seperti perempuan. Perbedaan dari laki-laki dan perempuan merupakan dari jens kelaminnya.

Istilah gender diperkenalkan oleh para ilmuwan sosial untuk menjelaskan perbedaaan perempuan dan laki-laki yang bersifat bawaan sebagai ciptaan Tuhan dan yang bersifat bentukan budaya yang dipelajari dan disosialisasikan sejak kecil. Perbedaan ini sangat penting karena selama ini sering sekali mencampur adukan ciri-ciri manusia yang bersifat kodrati dan yang bersifat bukan kodrati. Perbedaan peran gender ini sangat membantu kita untuk memikirkan kembali tentang pembagian peran yang selama ini dianggap telah melekat pada manusia perempuan dan laki-laki untuk membentuk gambaran relasi gender yang dinamis dan tepat serta cocok dengan kenyataan yang ada dalam masyarakat. Perbedaan konsep gender secara sosial telah melahirkan perbedaan peran perempuan dan laki-laki dalam masyarakatnya. Secara umum adanya gender telah melahirkan perbedaan peran, tanggung jawab, fungsi dan bahkan ruang tempat dimana manusia beraktivitas. Sedemikian rupanya perbedaan gender ini melekat pada cara pandang kita, sehingga kita sering lupa seakan-akan hal itu merupakan seseuatu yang permanen dan abadi sebagaimana permanen dan abadinya ciri biologis yang dimiliki oleh perempuan dan laki-laki.

Kata "gender" dapat diartikan sebagai perbedaan peran, fungsi, status dan tanggungjawab pada laki-laki dan perempuan sebagai hasil dari bentukan (konstruksi) sosial budaya yang tertanam lewat proses sosialisasi dari satu generasi ke generasi berikutnya. Dengan demikian gender adalah hasil kesepakatn antar manusia yang tidak bersifat kodrati. Oleh karenanya gender bervariasi dari satu tempat ke tempat lain dan dari satu waktu ke waktu berikutnya. Gender tidak bersifat kodrati, dapat berubah dan dapat dipertukarkan pada manusia satu ke manusia

\footnotetext{
${ }^{1}$ Fibrianto, 2016, "Kesetaraan Gender Dalam Lingkup Organisasi Mahasiswa Universitas Sebelas Maret Surakarta Tahun 2016”, dalam Jurnal Analisa Sosiologi, hal:10-27.
} 
lainnya tergantung waktu dan budaya setempat.3 Dengan demikian, gender menyangkut aturan sosial yang berkaitan dengan jenis kelamin manusia laki-laki dan perempuan. Perbedaan biologis dalam hal alat reproduksi antara laki-laki dan perempuan memang membawa konsekuensi fungsi reproduksi yang berbeda (perempuan mengalami menstruasi, hamil, melahirkan dan menyusui; laki-laki membuahi dengan spermatozoa). Jenis kelamin biologis inilah merupakan ciptaan Tuhan, bersifat kodrat, tidak dapat berubah, tidak dapat dipertukarkan dan berlaku sepanjang zaman.

Namun demikian, kebudayaan yang dimotori oleh budaya patriarki menafsirkan perbedaan biologis ini menjadi indikator kepantasan dalam berperilaku yang akhirnya berujung pada pembatasan hak, akses, partispasi, kontrol dan menikmati manfaat dari sumberdaya dan informasi. Akhirnya tuntutan peran, tugas, kedudukan dan kewajiban yang pantas dilakukan oleh laki-laki atau perempuan dan yang tidak pantas dilakukan oleh laki-laki atau perempuan sangat bervariasi dari masyarakat satu ke masyarakat lainnya. Ada sebagian masyarkat yang sangat kaku membatasi peran yang pantas dilakukan baik oleh laki-laki maupun perempuan, misalnya tabu bagi seorang laki-laki masuk ke dapur atau menggendong anaknya didepan umum dan tabu bagi seorang perempuan sering keluar rumah untuk bekerja. Namun demikian, ada juga sebagai masyarakat yang fleksibel dalam memperbolehkan laki-laki dan perempuan melakukan aktivitas sehari-hari, misalnya perempuan diperbolehkan bekerja sebagai kuli bangunan sampai naik ke atas rumah atau memanjat pohon kelapa, sedangkan laki-laki sebagian besar menyabung ayam untuk berjudi.

Pengurangan Resiko Bencana (PRB) harus di sosialisasikan kepada masyarakat Indonesia. Hal ini disebabkan Indonesia adalah daerah rawan bencana. Untuk itulah upaya pemerintah melakukan PRB sudah diperkuat dengan dikeluarkan UU tentang penanggulangan bencana. Namun demikian, belum dipahami secara optimal oleh masyarakat Undang-Undang No. 24 tahun 2007 tentang penanggulangan bencana mendefinisikan bencana sebagai peristiwa atau rangkaian peristiwa yang mengancam, mengganggu kehidupan dan penghidupan masyarakat yang disebabkan baik oleh faktor alam dan faktor non alam maupun faktor manusia. Sehingga mengakibatkan timbulnya korban jiwa, kerugian harta benda, dan dampak manusia untuk mengatasi masalah bencana belum banyak dilakukan secara sistematik dan suistanable sehingga korban bencana masih menunjukkan angka-angka relatif tinggi.

Dalam konteks inilah, Reaksi Aksi Nasional Pengurangan Resiko Bencana (RAN-PRB) merupakan suatu tindakan yang harus dirancang secara terpadu dan terencana. Hal ini didukung oleh kondisi Indonesia yang memiliki kerentanan bencana. Indonesia berada pada urutan ketujuh sebagai negara yang mengalami bencana alam terhadap resiko bencana belum dilaksanakan secara optimal. Artinya bahwa Indonesia sebagai daerah rawan bencana masih memiliki tiga masalah utama: Masih rendahnya kinerja penanganan bencana; Masih rendahnya perhatian perlunya pengurangan resiko bencana; dan Masih lemahnya peran sekolah dalam pendidikan mitigasi bencana.

Realitas ini menjadi tantangan besar bagi bangsa Indonesia untuk secara serius mampu merancang resiko penanganan bencana secara kreatif dan proaktif. Untuk mendesain programprogram penanganan bencana diperlukan perubahan paradigma penanganan bencana di Indonesia.

Strategi yang dikembangkan untuk RAN-PRB membutuhkan kerja keras yang bersifat struktural, holistik, dan kontekstual artinya secara struktural paradigma yang dirancang merupakan satu kerja sistematik antar kepentingan global, regional dan nasional yang dalam

${ }^{3}$ Puspita, H, 2013, “Konsep, Teori Dan Analisis Gender”, dalam Jurnal Genderdan Keluarga, hal: 13 
prosesnya saling tergantung satu sama lain dapat dilakukan secara koordinatif. Demikian pula sifat kerja yang dilakukan pada setiap tataran harus bersifat holistik bukan parsial, sehingga hasilnya benar-benar optimal dalam upaya PRB. Sementara itu, secara kontekstual programprogram yang dirancang dalam upaya PRB perlu memperhatikan dimensi demografis, sosial budaya dan ekonomi masyarakat.

Penanggulangan bencana merupakan kegiatan yang berkaitan dengan tahap-tahap pencegahan, mitigasi, kesiapsiagaan, dan rekonstruksi. Kajian ini terfokus pada upaya PRB yang berupaya pada salah satunya adalah menurunkan kerentanan personal dan sosial terhadap bahaya-bahaya alam dan ulah manusia dengan lebih memperhatikan sumber permasalahannya. Dalam hal ini, yaitu dengan mempersiapkan guru agar mampu memberikan sosialisasi pengetahuan tentang bencana dan PRB sebagai dasar pengetahuan yang memerlukan pembelajaran sedini mungkin, sehingga tumbuh budaya mitigasi bencana baik sebelum, saat bencana dan pascabencana. $\mathrm{PRB} /$ mitigasi, esensinya pada serangkaian aktivitas mengurangi risiko bencana (dampak bencana) dan strategi mitigasi merupakan satu langkah proses manajemen bencana. Untuk itu, salah satu aspek dalam mitigasi yang terkait dengan penelitian ini adalah upaya penyadaran dan meningkatkan kapasitas guru dan siswa dalam menghadapi ancaman bencana.

Salah satu prioritas HFA 2005-2015 adalah peringatan dini yang perlu digali terus menerus baik dari segi teknologi maupun akar budaya masyarakat setempat yang secara historis sudah mempunyai cara penyelamatan. Dalam hal ini, prioritas aksi perlu identifikasi, dikaji dan diminitor risiko bencana tersebut, serta meningkatkan peranan dini, diawali dengan menggalakkan budaya ketahanan terhadap bencana dan bertumpu pada peningkatan pengetahuan tentang bahaya dan kerentanan fisik, sosial, kerentanan itu dapat berubah dalam waktu dekat atau panjang akan diikuti oleh pemahaman atau pengetahuan terhadap bencana tersebut. "Not the song but the singer" demikian kata pepatah, maka sistem peringatan dini secanngih apapun sangat tergantung kesadaran akan masyarakatnya untuk bertindak sesuai dengan prinsip-prinsip Pengurangan Risiko Bencana. Akhirnya, kerentanan sosial-personal (psikososial) menjadi penting untuk dikaji dan ditingkatkan SDMnya. Termasuk didalam penelitian ini adalah meningkatkan kesadaran PRB dan resiliensinya baik sebelum maupun saat bencana dan juga setelah bencana yang membutuhkan kompetensi psikososial / relisiensi. Sekolah mempunyai peran strategis dalam upaya mitigasi bencana. Oleh karena itu, perlu membangun kapasitas guru agar memahami konsep yang benar tentang kebencanaan, pelatihan formal dan kolaborasi dengan institut pendidikan, serta mengintekgrasikan pemahaman PRB dalam pelatihan guru-guru.

Dari perspektif psikososial, upaya memahami kondisi siswa secara kognitif sampai dengan tindakan / decision dalam merespon bencana. Mekanisme pikiran, tanggapan dan respon terhadap bencana tersebut diharapkan dapat dijadikan sebagai indikator tingkat pemahaman asessment siswa secara cermat dan utuh dalam arti seberapa tingkat kesadaran akan resiko bencana maupun respon secrta mitigasi yang telah menjadi pengetahuan dan perspektifnya. Keutuhan dalam berpikir untuk memahami bencana atau khususnya resiko melalui dinamika berpikir dan bertindak dalam ORID (Objektive, Reflektive, Interpretative, and Decision).

Indikator tersebut diungkap dengan pertanyaan-pertanyaan pada proses mengingat kembali:

a) Sejauh mana tingkat sensifitas siswa dalam merespon bencana melalui kemampuan sensorinya $(\mathrm{O})$;

b) Sejauh mana tingkat reflektif siswa dalam menghayati pengalaman bencana mereka atau reaksi internal (membandingkan dengan kondisi sebelum dan sesudah terjadi bencana, ketakutan dan mungkin pengalaman positif lainnya (R); 
c) Sejauh mana kesadaran realitas yang dialami perempuan, ini membutuhkan kemampuan siswa, sehingga pengaruh langsung tidak terhadap sekolah, keluarga dan masa depan menjadi penting untuk diungkapkan (I);

d) Dengan tahap-tahap pikiran dan respon yang dialami pada 1-3, kemudian siswa akan membangun komitmen untuk menghadapi bencana dan adaptasi terhadap berbagai perubahan yang dialami oleh masing-masing siwa sebagai keputusan pribadinya.

Mitigasi dapat dilakukan secara non-struktural lenih menekankan kepada peningkatan kapasitas masyarakat. Upaya mitigasi ini dapat dilakukan melalui penyebaran informasi dilakukan antara lain dengan cara: memberikan poster dan leaflet kepada masyarakat yang bermukim pada daerah rawan bencana, tentang menggali, mencegah penanganan bencana.

a) Pemberian informasi

Pemberian informasi berupa poster atau rambu turut membantu memberikan kesadaran akan pentingnya upaya mitigasi bencana. Poster dan rambu ini perlu diperbanyak dan dipelihara sehingga masyarakat luas, baik yang tinggal di pemukiman rawan maupun tidak mampu secara sadar mengerti tentang bahaya bencana alam ini.

b) Sosialisasi

Kegiatan sosialisasi secara aktif dilakukan setiap bulan di lokasi yang berbeda-beda, baik itu dari wilayah rawan bencana maupun wilayah non rawan bencana. Sosialisasi yang dilakukan juga melibatkan beberapa stakeholders, diantaranya Kantor Kesatuan Bangsa, Politik dan Perlindungan Masyarakat, Dinas Sosial, Tenaga Kerja dan Transmigrasi, Bagian Kesejahteraan Rakyat, serta dibantuTNI dan Polri.

c) Pelatihan dan Simulasi Bencana

Gladi evakuasi atau simulasi bencana dibuat untuk lebih mempersiapkan masyarakat kepada kondisi nyata apabila terjadi bencana alam yang sesungguhnya. Apa yang akan dilakukan, barang-barang apa saja yang akan dibawa dan ke arah mana harus menyelamatkan diri serta siapa yang diselamatkan terlebih dahulu dari lain sebagainya. Simulasi bencana dilakukan untuk lebih kepada mempersiapkan kondisi masyarakat dalam mengahadapi bencana dan mengurangi situasi panik sebagai dampak ikutan dari bencana yang dapat menambah jatuhnya korban. ${ }^{4}$

Perlu adanya wujud yang nyata agar kaum perempuan bisa ikut serta menjadi relawan. Hal ini menjadi momok yang sangat menarik untuk diteliti dalam pembahasan ini. Tujuan penelitian ini adalah untuk mengetahui rasa kemanusiaan pada perempuan, mengembangkan rasa pengembangan pada jiwa perempuan dalam penanggulangan bencana dan mewujudkan pengembangan pada jiwa perempuan dalam penangulangan bencana.

\section{METODE}

Penelitian ini berbasis pada kajian pengalaman di kehidupan, melihat kejadian yang sering terjadi di Indonesia. Pendekatan ini meliput apa saja kejadian bencana yang sudah terjadi di dunia ini. Pendekatan adalah cara pandang atau paradigma yang terdapat dalam suatu bidang ilmu yang selanjutnya digunakan dalam memahami agama. Dalam hubungan ini, Jalaluddin Rahmat mengatakan bahwa agama dapat diteliti dengan menggunakan berbagai macam paradigma. Pendekatan juga bisa diartikan sebagai cara memandang atau memahami sesuatu

\footnotetext{
${ }^{4}$ Rahman, A, 2015, “Kajian Mitigasi Tanah Longsor Di Kabupaten Banjarnegara”, dalam jurnal Managemen dan Kebijakan Publik, hal: 7-8.
} 
fenomena yang terjadi dengan menggunakan ilmu sosiologi tentang bagaimana sifat, perilaku dan perkembangan masyarakat tentang struktur sosial, proses sosial dan perubahannya.

Metode yang digunakan dalam penelitian ini melalui pendekatan phenomenologi dan sosiologi yaitu fenomena dan kegiatan penanggulangan bencana oleh perempuan untuk membaca pengembangan rasa kemanusiaan pada jiwa perempuan dalam penanggulangan bencana. Sedangkan, rasa kemanusiaan pada perempuan dijelaskan melalui pendekatan konten analisis. Pendekatan phenomenoloogi atau dikenal dengan fenomenologi. Pada awalnya fenomenologi merupakan kajian filsafat dan sosiologi. Edmund Husserl sendiri penggagas utamanya, dia mengingikan femenologi akan melahirkan ilmu yang lebih bisa bermanfaat bagi kehidupan manusia, setelah sekian lama ilmu pengetahuan mengalami krisis dan disfungsional. Fenomenologi kemudian berkembang sebagai semacam metode riset yang diterapkan dalam berbagai ilmu sosial, termasuk di dalamnya komunikasi sebagai salah satu varian dalam penelitian kualitatif dalam payung paradigma interpretif.

Pada awalnya, istilah fenomenologi diperkenalkan oleh J.H Lambert pada tahun 1764 untuk menunjukkan pada Teori Kebenaran. Femenologi dicetuskan secara intens sebagai kajian filsafat pertama kali oleh Edmund Husserl (1859-1938), sehingga Husserl sering dibandang sebagai Bapak Femenologi. Filsafatnya sangat populer sekitar tahun 1950-an. Tujuan utama filsafat ini adalah memberi landasan bagi filsafat agar dapat berfungsi sebagai ilmu yang murni dan otonom. Pada awal perkembangannya, femenologi merupakan seperangkat pendekatan dalam studi filosofis dan sosiologis, serta studi tentang seni.

Femenologi merupakan salah satu pendekatan yang digunakan dalam penelitian kualitatif. Metode kualitatif hadir sebagai respons terhadap keberadaan metode kuantitatif yang dianggap tidak mampu lagi menjawab berbagai persoalan kehidupan yang ada. Metode ini memposisikan manusia sebagai subjek penelitian bukan sebagai objek penelitian (metode kuantitatif) yang mendapat sedikit porsi di dalamnya. Metode kualitatif dengan pendekatan femenologi berupaya untuk menangkap berbagai persoalan yang ada di masyarakat dan mengungkap makna yang terkandung di dalamnya.

Sedangkan yang pendekatan sosiologi berasal dari kata sociusyang berarti kawan, teman sedangkan logos berarti ilmu pengetahuan. Umunya sosiologi ini adalah ilmu yang mempelajari masyarakat meliputi gejala-gejala sosial, struktur sosial, perubahan sosial dan jaringan hubungan atau interaksi manusia sebagai makhluk individu dan makhluk sosial. Sosiologi adalah ilmu yang aktif hidup bersama dalam masyarakat dan menyelidiki ikatan-ikatan antara manusia yang menguasai kehidupan ini. Sementara itu, Soerjono Soekarno mengartikan sosiologi sebagai suatu ilmu pengetahuan yang ada pada sifat penilaian. Sosiologi tidak ditetapkan ke arah mana sesuatu struktural berkembang dalam arti memberi petunjuk-petunjuk yang lagi kebijaksanaan kemasyarakatan dari proses kehidupan bersama tersebut. Jika disimpulkan arti dari pendekatan sosiologi tersebut adalah suatu landasan kajian sebuah studi atau peneliti sebuah untuk edisi hidup bersama dalam masyarakat.

Untuk itu pendekatan fenomenologi dan sosiologi sangat berpengaruh untuk pengembangan jiwa perempuan dalam penanggulangan bencana. Dari sini dapat diketahui rasa kemanusiaan yang ada pada saat membantu korba bencana alam. Dalam perspektif sosiologis, bencana seringkali dipahami berdasarkan persepsi manusia tau masyarakat dan atas apa yang mereka rasakan terkait pengalaman emosional pada kejadian-kejadian yang dapat mengancam kelangsungan hidup mereka. Bencana merupakan salah satu bagian definisi yang disusun dalam suatu konteks sosial budaya hidup masyarakat yang mengalami bencana. Suatu kejadian bencana ditandai dengan terjadinya kerusakan pola sosial dan ekonomi komunitas yang normal ada sebelumnya. 
Dengan pendekatan sosiologis dapat menimbulkan prespektif atau pandangan yang berbeda mengenai gejala sosial yang terjadi, sehingga dalam memandang Islam tidak hanya dari satu sisi saja, serta tidak menimbulkan klaim kebenaran tunggal. Dengan pendekatan ini, kita dapat memandang atau memahami gejala-gejala sosial disekitar kita, kita dapat mengetahui bagaimana hubungan antara individu dengan lingkungan atau individu dengan individu. Bagaimana lingkungan mempengaruhi individu atau sebaliknya, individu mempengaruhi lingkungan.

\section{HASIL DAN PEMBAHASAN}

Adanya kesetaraan gender menjadikan derajat perempuan terangkat dalam menjalakan kekuasaanya juga. Perlunya mewujudkan dan mengembangkan apa yang sudah menjadi relawan pada sebagian perempuan.

Pertama, Rasa Kemanusiaan pada Jiwa PerempuanPartisipasi perempuan saat ini, bukan sekedar menuntut persamaan hak seserorang tetapi juga menyatakan fungsinya mempunyai arti bagi pembagunan dalam kemajuan masyarakat Indonesia. Melihat potensi perempuan sebagai sumber daya manusia maka upaya menyertakan perempuan dalam proses pembangunan bukan hanya merupakan peri kemanusiaan biasa belaka, tetapi merupakan tindakan efisien karena tanpa mengikutsertakan perempuan dalam proses pembangunan tidak akan terjadi pengaruh yang besar dalam perubahan negeri ini. Keberadaan perempuan dalam keikutsertaan menjadi relawan dalam menangani korban bencana mempunyai arti tersendiri yang tidak bisa dipandang sebelah mata saja.

Untuk memahami psikologi perempuan secara komperehensif, terlebih dahulu perlu memahami karakteristik fisiologis mereka yang mengandung perbedaan dan persamaan laki-laki. Perlakuan yang berbeda dan ketidak-adilan yang diterima perempuan selalu berpangkal dari perbedaan secara anatomis fisiologis antara perempuan dan laki-laki. Perbedaan fisik pada perempuan merupakan takdir dengan istilah freud yang dikenal Anatomy is destiny, tetpai tidak meniscayakan relasi antar jenis kelamin yang berbeda itu menimbulkan kesenjangan dan bersifat hirakhis, karena relasi antar kedua makhluk Tuhan penghuni bumi itu bukan takdir, tetapi dikonstruksi secara sosial.

Sinergi dari dua karakteristik fisik yang berbeda antar laki-laki dan perempuan itu akan melahirkan kehidupan harmoni yang saling mendukung satu sama lain, ibarat tangan kiri dan tangan kanan yang bergantian menjuntai ke depan dan ke belakang pada saat digunakan untuk berjalan, sehingga perjalanan akan sampai kepada satu tujuan yang sama, hal tersebut tidak berarti tangan kanan atau tangan kiri yang paling penting. Tetapi, kedua dari bagian itu sangat dibutuhkan untuk kelengkapan satu sama lain. Seperti adanya laki-laki dan perempuan, disini bukan berarti laki-laki yang paling penting dalam membantu korban bencana tetapi perempuan juga berarti penting dalam kegiatan membantu penanganan korban bencana alam tersebut.

Rasa kemanusiaan pada jiwa perempuan mempunyai nilai-nilai kemanusiaan (Human Values) merupakan nilai-nilai yang sifatnya universal dan dapat dikembangkan untuk membentuk karakter pada jiwa perempuan. ${ }^{5}$ Rasa kemanusiaan pada perempuan itu sudah ada sejak mereka lahir ke dunia, karena jiwa kemanusiaan selalu menggeluti personal dan selalu menuju dalam kebaikan. Adanya rasa kemanusiaan juga terdapat di dalam pancasila sila kedua yang berbunyi " kemanusiaan yang adil dan beradab ", dari situ sudah jelas bahwa negara Indonesia juga menjunjung tinggi rasa kemanusiaan dalam kehidupannya. Nilai-nilai kemanusiaan yang diaplikasikan dalam membantu menangani korban bencana alam seperti menenangkan

\footnotetext{
${ }^{5}$ Sukayasa dan Evie, A, "Pengintegrasian Nilai-Nilai Kemanusiaan (Human Values) Dalam Pembelajaran Tematik Sekolah Dasar", hal: 54-61.
} 
penduduk yang kehilangan anggota keluargannya karena di sisi lain mereka trauma juga menghadapi masa yang sangat sulit yaitu kehilangan anggota keluarganya. Menyumbangkan beberapa baju, memberinya sembako, memberikan tempat berteduh. Seperti itulah rasa kemanusiaan yang berada pada jiwa perempuan. Walaupun tindakan seperti itu sangat sederhana tetapi sangat berarti pula bagi mereka yang membutuhkan perilaku kemanusiaan seperti itu.

Bantuan kemanusiaan dengan konsep humanitarian menekankan pada usaha untuk menghilangkan penderitaan manusia yang terjadi akibat krisis atau bencana. Prinsip tersebut merupakan komitmen paling utama dalam aksi kemanusiaan yang dilakukan oleh berbagai aktor dalam aksi kemanusiaan. Kata "bencana" sendiri merupakan kunci bagi keterlibatan berbagai pihak dalam penanganan bencana. Dalam kondisi jatu seperti ini, dibutuhkan kesiapan berbagai pihak dalam penanggulangan pasca bencana. ${ }^{6}$ Rasa kemanusiaan disini sangat berpengaruh bagi korban yang mengalami bencana alam tersebut.

Rasa kemanusiaan berarti aksi kemanusiaan yang mengutamakan penyelamatan kehidupan manusia dan menghilangkan penderitaan. Seperti contohnya gempa bumi di Aceh yang mengakibatkan kota Aceh hancur bagai kapal pecah, seperti itu sangat membutuhkan bantuan kemanusiaan yang rela demi mereka yang menjadi korban bencana tersebut.

Di negara-negara industri, tanggap bencana alam umumnya dikelola oleh negara dan masyarakat yang terkena bencana, sebagaimana yang dilihat dalam respons Amerika terhadap Katriana, respons Jepang terhadap gempa bumi Kobe dan yang lebih dekat respons Cina terhadap gempa bumi Sichuan. Dalam berbagai contoh tersebut, orang-orang yang terkena bencana menjadi aktor utama dalam pemulihan mereka sendiri, dengan dibiayai dan dipimpin untuk sebagian besar oleh otoritas nasional dan regional. Penghargaan kepada "kepemilikan" semacam ini merupakan prinsip bantuan kemanusiaan internasional.

Di negara-negara "non industri", sebagaimana contohnya jangkaun bencananya melampaui kapasitas lokal untuk menanggapi secara efektif, sederetan panjang aktor kemanusiaan semakin menjadi terlibat. Ini diilustrasikan dengan jelas oleh respons intensif terhadap Tsunami Samudra Hindia 2004, khususnya di Indonesia dan Sri Lanka. Peningkatan dramastis dana yang yang dipercayakan kepada aktor -aktor bantuan kemanusiaan internasioanal telah mendorong mereka untuk berperan lebih menonjol di berbagai latar pascabencana. Tetapi mereka menghadapi berbagai kendala dan tantangan besar dalam merancang dan melaksanakan program pemulihan. Walaupun ada banyak kasus "praktik yang baik", disini menitikberatkan rasa dan tindakan kemanusiaan dalam membantu korban bencana tersebut. ${ }^{7}$

Kedua, Pengembangan Jiwa Kemanusiaan dalam Penanganan BencanaPengetahuan tentang bencana alam meruapakan modal awal pengembangan jiwa kemanusiaan pada perempuan. Pengetahuan sendiri adalah dasar tindak dan tingkah laku manusia. Begitu juga pengetahuan kebencanaan akan sangat penting untuk menentukan sikap dan tindakan dalam menghadapi bencana. Perempuan dalam upaya pengembangan penanggulangan bencana perlu didasari oleh pengetahuan, sehingga sikap mereka menimbulkan tindakan yang tepat. Perempuan memang memiliki resiko kerentaan yang lebih banyak daripada laki-laki, meskipun perempuan memiliki kerentaan dan daya tahan yang berada dibawah laki-laki tidak akan menyudutkan semangat jiwa perempuan dalam upaya penanganan korban bencana alam.

\footnotetext{
${ }^{6}$ Sinulingga, A, 2016, "Isu Bencana dan Prinsip-Prinsip Humanitarian Dalam Studi Ilmu Hubungan Internasional", Andalas Journal of International Studies, hal: 23.

${ }^{7}$ Daly, Patrick, dkk, 2012, “Aceh Pasca Tsunami dan Pasca Konflik”, Bali : Pustaka Larasan, hal: 37-38.
} 
Pengembangan jiwa kemanusiaan pada perempuan dalam penanggulangan bencana memiliki prinsip-prinsip umum yang meliputi orang-orang yang terkena dampak bencana alam harus menikmati hak-hak dan kebebasan-kebebasan yang sama menurut hukum HAM di negara mereka dan tidak boleh menerima perlakuan diskriminatif. Tindakan-tindakan dengan sasaran tertentu untuk memenuhi kebutuhan-kebutuhan bantuan dan perlindungan bagi penduduk yang termasuk dalam kategori khusus yang terkena dampak bencana tidak bisa dianggap diskriminantif, jika berdasarkan kebutuhan-kebutuhan yang berbeda.

Penyediaan obat dalam situasi bencana merupakan salah satu unsur penunjang yang sangat penting dalam pelayanan kesehatab pada saat bencana. Oleh karena itu diperlukan adanya persediaan obat dan perbekalan kesehatan sebagai penyangga bila terjadi bencana mulai dari tingkat kabupaten diteruskan ke tingkat provinsi sampai pusat. Tersedianya pelayanan kesehatan menjadi mempermudah penyembuhan korban dari bencana alam yang terjadi.

Bencana alam yang terjadi di alam ini masing-masing memiliki tingkatan yang berbeda-beda. Begitu pula penanganan korban juga berbeda-beda. Penentuan kategori bencana tentunya berbeda antarnegara bahkan antardaerah dalamsuatu negara. Sebagai contoh secara umum dikenal dengan jenis-jenis bencana seperti kekeringan, gempa bumi, epidemi, temperatur ekstrim, banjir, tanah longsor, gelombang laut (termasuk tsunami), kebakaran dan angin ribut. Di suatu negara tertentu, epidemi yang terjadi kemungkinan besar dipilah-pilah kembali dalam kelas-kelas seperti demam berdarah dan flu burung. Contoh lain, kategori bencana banjir terpilah lebih rinci yang diantarannya banjir luapan sungai, banjir karena mis-management luapan air hujan dan banjir karena luapan air dari unpredicted cases. Inti dari dari perbedaan dasar penentuan kategori bencana ini adalah adanya bedatentang informasi bencana, yang berlanjut pada beda untuk managemen informasi dan beda strategi nasional untuk penanganan bencana, tanpa harus terjebak pada mimpi besar tentang upaya menciptakan sistem informasi bencana.

Harus diingat bahwasanya bila suatu sistem informasi bencana diciptakan, maka sistem ini tidak saja sekedar menjadi sistem yang hanya terkait dengan bencana alam, namun harus pula mampu mewadahi bencana kemanusiaan lainnya seperti, terorisme, pelanggaran hak asasi manusia dan bahkan kejahatan. Pengembangan jiwa kemanusiaan dalam penanggulan bencana dapat dilakukan dengan cara pertama, melancarkan dana dari negara karena memiliki tugas dang tanggung jawab utama menyediakan bantuan untuk orang-orang yang terkena dampak bencanabencana alam dan melindungi HAM mereka. Dengan cara seperti ini korban lambat laun akan bisa mengurangi cidera dari bencana alam yang sudah menghantui pikiran mereka.

Selain itu ada cara yang kedua, ini dilakukan agar korban bencana tidak takut berkepanjangan. Mereka selayaknya bisa mengakses informasi mengenai sifat dan tingkat bencana yang dihadapi, kemungkinan berbagai tindakan pengurangan resiko yang bisa dilakukan, informasi peringatan dini dan informasi tentag bantuan kemanusiaan yang sedang berlangsung, upayaupaya pemulihan dan hak-hak yang wajib mereka dapatkan.

Tugas dan tanggung jawab utama untuk menyediakan perlindungan dan bantuan itu diemban para pejabat nasional di negara-negara terkena dampak bencana. Mereka yang terkena dampak bencana-bencana alam berhak meminta dan mendapat perlindungan dan bantuan itu dari pemerintah-pemerintah mereka. Dari sini dapat dipahami bahwasanya tidak ada perbedaan pemberian bantuan untuk korban bencana laki-laki maupun perempuan. Semua dari mereak adalah sama yang harus dibantu. Begitu juga dengan relawan yang membantu, mereka juga tidak membedakan yang harus membantu itu harus dari kaum laki-laki atau sebaliknya. Semuanya sama-sama meliki ikut serta yang penting keduanya dan saling melengkapi.

Laki-laki dan perempuan saling melengkapi dalam membantu korban bencana alam, bisa dengan membagi tugas untuk kaum laki-laki langsung terjun ke tempat terjadinya bencana. 
Sedangkan yang perempuan bisa membantu menenangkan dan mengurusi korban bencana alam semisal gempa yang sudah ditemukan. Bisa juga perempuan yang terjuan langsung ke tempat terjadinya perkara, sedangkan laki-laki yang mengurusi korban yang sudah ditemukan. Keduanya sama-sama penting dan sama-sama dibutuhkan.Perempuan harus bisa bangkit dari tradisi jaman klasik yang mengharuskan perempuan untuk tinggal dirumah saja. Tapi saat ini, ada kesetaraan gender yang menyamakan derajat kekuasaan perempuan dengan laki-laki.

Ketiga, Perwujudan Pengembangan rasa kemanusiaanPerempuan sering kali mengalami kendala dalam mewujudkan pengembangan rasa kemanusiaan dalam penanganan korban bencana alam. Terdapat beberapa hal dalam psikologi perempuan dapat dikemukakan antara lain:pertama, Psikologis perempuan dipandang dependen, berwatak mengasuh dan merawat. Pandangan tersebut masih susah dibedakan kebenarannya, sebab dalam realitas kehidupan cukup banyak laki-laki yang berwatak mengasuh dan cukup banyak laki-laki yang berwatak merawat.

Kedua, Psikologis perempuan selalu mengalah, menyetujui, menyesuaikan diri dan menyenangkan orang lain. Perilaku kasar, asertif, suak berkelahi dan agresif dipandang sebagai citra laki-laki. Dengan demikian perempuan yang dicitrakan lemah dan pasif, sedangkan lakilaki aktif dan agresif merupakan citra bias gender, karena dikonstruksian oleh lingkungan dan budaya masyrakat, bukan merupakan citra yang terberi atau kodrat.Ketiga, Psikologis perempuan itu emosional dan mudah menangis. Berdasarkan studi observasi terhadap perempuan dan laki-laki, ditemukan bahwa anak laki-laki lebih sering menangis ketika masih bayi dan sedang belajar berjalan dengan terlatih daripada anak perempuan, tetapi perempuan dewasa dan tua lebih sering menangis daripada laki-laki.

Keempat, Psikologis perempuan yang penakut dan sensitif. Beradasarkan penelitian, anak perempuan dan anak laki-laki prasekolah sama-sama berjiwa berpetualang. Tetapi menginjak dewasa perempuan lebih penakut dibanding laki-laki. Jika laki-laki menjadi penakut akan dicemooh teman-temanya. Kelima, Psikologi perempuan yang lemah dan tidak berprestasi. Minimnya jumlah perempuan yang ahli di bidang sains, politik dan ekonomi dipandang citra perempuan yang lemah disebabkan ketidakmampuannya dalam mengejar prestasi seperti yang dicapai laki-laki. Padahal menurut Maccoby dan Jacklin, perempuan tidak berprestasi disebakan ada rasa takut akan sukses (fear of succes), bukan tidak mampu berprestasi. Pendapat tersebut diperkuat oleh studi Maslow pada tahun 1942 yang menemukan, perempuan yang memiliki keyakinan kuat bahwa dirinya berharga, cenderung memiliki sifat mandiri, asertif dan sukses. Menurutnya setiap individu perempuan maupun laki-laki berusaha memenuhi kebutuhannya secara hirakhis, dan kebutuhan manusia yang paling tinggi adalah mampu mengaktualisasikan dirinya. Seperti itu sejalan dengan pemikiran masyaratnya untuk memberikan kekuasaan atau tidak terhadap perempuan.

a) Psikologis perempuan yang mudah terpengaruh dan mudah dibujuk;

b) Psikologis perempuan lebih sensitif terhadap perilaku non verbal;

c) Psikologis perempuan lebih ekspresif. Tetapi perilaku perempuan seperti ini tergantung pada keadaan tempat dan masyarakat. ${ }^{8}$

Perbedaan seperti itu dinamakan dengan gender, Heddy Shri Ahimsha menegaskan bahwa istilah Gender dapat dibedakan ke dalam beberapa pengertian berikut ini: Gender sebagai sebagai suatu istilah asing yang bermakna tertentu, Gender sebagai suatu fenomena sosial budaya, Gender sebagai sebuah konsep untuk analisis, Gender sebagai fenomena dalam sebuah

${ }^{8}$ Nurhayati. E, 2012, "Psikologi Perempuan Dalam Berbagai Perspektif”, Yogyakarta, Pustaka Pelajar, hal: $28-33$ 
kenyataan. Jadi adanya kesetaraan gender tergantung pada masyarakat yang berada di sekitar mereka. ${ }^{9}$

Perwujudan penanggulangan bencana dalam jiwa perempuan dapat dilakukan dengan perencanaan penanggulangan bencana, pengurangan risiko bencana, pencegahan, pemanduan dalam perencanaan pembangunan, situasi terdapat potensi terjadinya bencana, pendidikan dan pelatihan. ${ }^{10}$ Dengan seperti ini perempuan juga bisa ikut serta dalam membantu korban bencana alam.

Perempuan memiliki peran yang sangat straregis dalam menghadapi bencana agar resiko yang ditimbulkan akibat bencana dapat ditekan melalui upaya meningkatkan peran perempuan dalam mengurangi risiko bencana dapat melalui peningkatan :

a) Kesadaran perempuan dalam memahami situasi lingkungan dan ancaman bahaya yang akan terjadi;

b) Pemahaman tentang kerentanan dan kemampuan untuk mengukur kapasitas yang dimiliki oleh masing-masing perempuan;

c) Kemampuan untuk menilai risiko yang dihadapi perempuan sebagai individu, anggota keluarga dan masyarakat;

d) Kemampuan untuk merencanakan dan melakukan tindakan untuk mengurangi risiko yang dimiliki baik melalui peningkatan kapasitas dan mengurangi kerentanan;

e) Kemampuan perempuan untuk memantau, mengevaluasi, dan menjamin keberlangsungan upaya pengurangan risiko sehingga dampak bencana dapat dikurangi maupun dicegah. ${ }^{11}$

Dampak dan penanggulangan bencana alam berbeda-beda, tergantung dari kapsitas bencana yang melanda. Pada umumnya masyarakat Indonesia, membagi pekerjaan antar laki-laki dan perempuan. Basis awal pembagian kerja menurut jenis kelamin ini tidak diragukan lagi terkait dengan keberadaan peran laki-laki dan perempuan dalam fungsi reproduksi. Dalam penanganan bencana perempuan cenderung menjadi relawan yang memberi makanan korban, sedangkan laki-laki mengobati dan mencari korban bencana yang hilang. ${ }^{12}$ Namun, perempuan juga bisa bekerja seperti laki-laki, hal tersebut tergantung kebiasaan sosial yang terjadi.

\section{SIMPULAN}

Perbedaan gender sebenarnya tidak menjadi masalah sepanjang tidak melahirkan ketidakadilan gender. Masalah itu akan muncul ketika perbedaan gender telah melahirkan berbagai ketidakadilan, terutama bagi kaum perempuan. Rasa kemanusiaan merupakan rasa yang terkandung di dalam jiwa manusia. Jiwa terletak di dalam diri manusia dan jiwa selalu memberi naluri pada manusia agar selalu melakukan tindakan yang baik. Rasa kemanusiaan itu bisa

${ }^{9}$ Kasmawati, 2013, “Gender Dalam Persfektif Islam”, hal: 55-67.

${ }^{10}$ Utami, D. R, 2016, "Partisipasi Perempuan Dalam Penanggulangan Bencana Pada Kegiatan Kesiapsiagaan Gunung Merapi Di Kabupaten Sleman Periode 2011-2015”.

${ }^{11}$ Hastuti, 2016, "Peran Perempuan Dalam Menghadapi Bencana Di Indonesia”, dalam Jurnal Geomedia, hal: 13-21.

${ }^{12}$ Ahdiah, I, 2013, “Peran-Peran Dalam Masyarakat”, dalam Jurnal Academica, hal: 1085-1091. 
seperti menolong orang yang terkena musibah.Perwujudan pengembangan rasa kemanusiaan dalam penanggulan bencana alam ini dengan perencanaan penanggulangan bencana, pengurangan risiko bencana, pencegahan, pemanduan dalam perencanaan pembangunan, situasi terjadinya bencana, pendidikan dan pelatihan.

\section{DAFTAR PUSTAKA}

Ahdiah, I, 2013, "Peran-Peran Dalam Masyarakat", dalam Jurnal Academica, Volume 5, Nomor 2 : 1085-1091.

Daly, Patrick, dkk, 2012, “Aceh Pasca Tsunami dan Pasca Konflik”, Bali : Pustaka Larasan.

Departemen Kesehatan RI, Jakarta, 2007, "Pedoman Teknis Penanggulangan Krisis Kesehatan Akibat Bencana", Jakarta:DEPKES RI.

Fibrianto,A.S, 2016, "Kesetaraan Gender Dalam Lingkup Organisasi Mahasiswa Universitas Sebelas Maret Surakarta Tahun 2016", dalam Jurnal Analisa Sosiologi, Volume 5, Nomor 1: 10-27.

Hastuti, 2016, "Peran Perempuan Dalam Menghadapi Bencana Di Indonesia", dalam Jurnal Geomedia, Volume 14, Nomor 2 : 13-21.

Kasmawati, 2013, “Gender Dalam Persfektif Islam”, Volume 1, Nomor 1: 55-67.

Nurhayati. E, 2012, "Psikologi Perempuan Dalam Berbagai Perspektif”, Yogyakarta : Pustaka Pelajar.

Puspita, H, 2013, “Konsep, Teori Dan Analisis Gender”, dalam Jurnal Genderdan Keluarga, Volume 1, Nomor 1:1-13

Prajarto, N, 2004, "Bencana, Informasi dan Keterlibatan Media”, Volume 1, Nomor 1: 1-24.

Rahman, A, 2015, "Kajian Mitigasi Tanah Longsor Di Kabupaten Banjarnegara”, dalam jurnal Managemen dan Kebijakan Publik, Volume 1, Nomor 1: 1-13

Sinulingga, A, 2016, "Isu Bencana dan Prinsip-Prinsip Humanitarian Dalam Studi Ilmu Hubungan Internasional", Andalas Journal of International Studies, Volume 5, Nomor 1 : 7-27.

Sukayasa dan Evie, A, "Pengintegrasian Nilai-Nilai Kemanusiaan (Human Values) Dalam Pembelajaran Tematik Sekolah Dasar" : 54-61.

Syamsul Maarif et al, 2012, "Konstestasi Pengetahuan Dan Pemaknaan Tentang Ancaman Bencana Alam”, dalam Jurnal Penanggulangan Bencana, Volume 3, Nomor 1: 1-13.

Utami, D. R, 2016, "Partisipasi Perempuan Dalam Penanggulangan Bencana Pada Kegiatan Kesiapsiagaan Gunung Merapi Di Kabupaten Sleman Periode 2011-2015”.

Vintasari. M. dan Fujiawati.F, "Peningkatan Peran Wanita Terhadap Penanggulangan Bencana Banjir Di Kawasan Rawan Bencana Banjir Kabupaten Serang”, dalam Jurnal GeoEco, Volume 4, Nomor 1: 1-8. 